
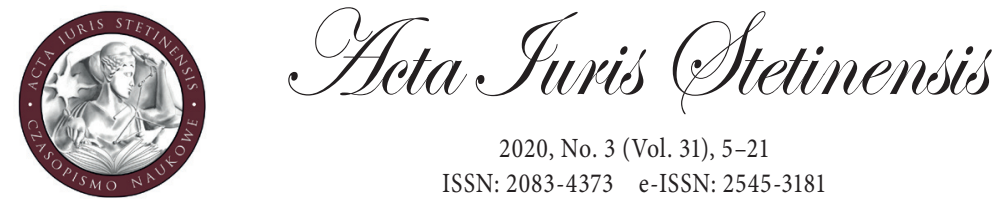

2020, No. 3 (Vol. 31), 5-21

ISSN: 2083-4373 e-ISSN: 2545-3181

DOI: $10.18276 /$ ais.2020.31-01

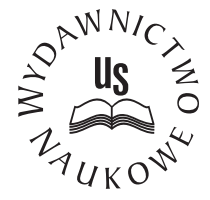

Łukasz Dawid Dąbrowski

Ph.D.

SGH Warsaw School of Economics, Poland

Collegium of World Economy

e-mail: ldabro@sgh.waw.pl

ORCID ID: 0000-0003-2251-7791

\title{
Application of Article 316 of the Polish Code of Civil Procedure in the appeals against decisions of the President of the Office of Electronic Communications
}

\begin{abstract}
In cases specified in Article 206 par. 2 of the Act on the Telecommunications Law, telecommunications entrepreneurs have the right to appeal to the Court of Competition and Consumer Protection in Warszawa. All provisions of the Code of Civil Procedure, including Article 316 of the CCP, apply to the CCCP procedure. Article 316 of the CCP concerns one of the basic issues of civil procedure, i.e. basis for judgement. However, the application thereof in telecommunications cases provokes certain reflections which lead to the conclusion in compliance with which Article 316 of the CCP is applicable in telecommunications cases when the specificity of these cases is taken into account, especially the fact that the CCCP procedure is supervisory in nature and checks the regulatory activities of the President of the Office of Electronic Communications. The paper analyses judicial decisions of ordinary courts and the Supreme Court in telecommunications cases, as well as social security and energy regulation cases, which due to the major similarities of appeals against decisions issued by ZUS and the President of ERO, and appeals against decisions issued by the President of the OEC, may be per analogiam applied to telecommunication cases.
\end{abstract}

Keywords: Office of Electronic Communications, civil procedure, Telecommunications Law, court's cognition 


\section{Introductory notes}

The telecommunications services market, on the grounds of the provisions of the Act of 16 July 2004 - the Telecommunications Law ${ }^{1}$ (hereinafter: 'the TL'), is subject to regulation by the President of the Office of Electronic Communications (hereinafter: the President of the OEC). Depending on the circumstances established in a given procedure, the President of the OEC can, by an administrative decision, stipulate the rights and obligations of telecommunications entrepreneurs. ${ }^{2}$ Article 206 of the TL provides for the possibility of appealing against administrative decisions issued by the President of the OEC. In compliance with Article 206 par. 1 of the TL, procedure before the President of the OEC runs on the basis of provisions of the Act of 14 June 1960 - the Code of Administrative Procedure ${ }^{3}$ (hereinafter: the CAP), as amended due to the Act on the Telecommunications Law and the Act of 7 May $2010^{4}$ on supporting development of telecommunications services and networks. ${ }^{5}$ Decisions of the President of the OEC, with the exception of decisions enumerated in par. 2 of Article 206 of the TL, are subject to review in administrative procedure in compliance with the rules stipulated in the CAP that is by submitting a motion for re-examination of the case by the President of the OEC. ${ }^{6}$ These decisions are then verified in the judicial-administrative procedure (a complaint to the Voivodeship Administrative Court, a cassation appeal to the Supreme Administrative Court). A special appeal mode has been provided for in par. 2 of Article 206 of the TL in compliance with which a decision can be appealed to the District Court in Warszawa - the Court of Competition and Consumer Protection (hereinafter: 'CCCP'). Article 206 par. 2 of the TL specifies decisions subject to this mode by indicating the object and/or type of decision, or Article of the TL providing for

1 Act of 16 July 2004 - Telecommunications Law, Dz.U. (Journal of Laws) of 2004, no. 171 item 1088 as amended.

2 Kledzik, P., Postępowanie przed Prezesem Urzędu Komunikacji Elektronicznej, in: Babis, H. and Flaga-Gieruszyńska, K. (eds.), Rynek usług telekomunikacyjnych, Warszawa 2011, p. 267.

3 Act of 14 June 1960 - Code of Administrative Procedure, consolidated text: Dz.U. (Journal of Laws) of 2013, item 267.

4 Act of 7 May 2010 on supporting development of telecommunications services and networks, consolidated text: Dz.U. (Journal of Laws) of 2010, no. 106 item 675.

5 Dąbrowski, Ł.D., Odmowa wydania decyzji przez Prezesa Urzędu Komunikacji Elektronicznej w'świetle art. 28 ustawy prawo telekomunikacyjne, "Ius Novum" 2016, No. 3, p. 315.

6 Piątek, S., Prawo telekomunikacyjne. Komentarz, Warszawa 2013, p. 1222.

7 Dąbrowski, Ł.D., Zastosowanie art. 321 k.p.c. $w$ sprawach z odwołań od decyzji Prezesa Urzędu Komunikacji Elektronicznej, "Ius Novum" 2016, No. 4, p. 158. 
issuance thereof. ${ }^{8}$ Provisions concerning the mode of procedure in telecommunications cases evolved in the direction of meeting requirements included in Article 4 of Directive 2002/21/EC of the European Parliament and of the Council of 7 March $2002,{ }^{9}$ and respectively, Article 31 of the European Electronic Communications Code,${ }^{10}$ which is to be implemented in domestic legal systems until 21 December 2020. ${ }^{11}$ Procedure before the CCCP is pending in compliance with the provisions of the Act of 17 November 1974 - the Code of Civil Procedure. ${ }^{12}$ This is a substantive, first instance procedure subject to general rules of examining cases, ${ }^{13}$ which results from adjusting legal regulations to regulatory requirements of the European Union. ${ }^{14}$

Decisions issued by the President of the OEC impose on telecommunications entrepreneurs' obligations concerning, ${ }^{15}$ among others, telecommunications access, non-discrimination, and costs. These are also decisions related to imposing penalties or giving rights e.g. related to the reservation of frequency ${ }^{16}$ or allocation of

8 In compliance with Article 206 par. 2 of the TL, a decision: 1) on determining a significant market position, 2) on imposing, waiving, changing or revoking regulatory obligations, 3 ) on imposition of a fine, 4) referred to in Article 43a and in Article 201 par. 3, 5) issued in disputes, with the exception of decisions on booking frequency after carrying out a tender, auction or contest and on decision on recognising the tender, auction or contest as unsolved, 6) referred to in Article 7 par. 1, Article 13 par. 2, Article 20, Article 21 par. 2, Article 22 and Article 30 of the Act of 7 May 2010 on supporting development of telecommunications services and networks - may be appealed to the District Court in Warszawa - the Court of Competition and Consumer Protection.

9 Directive 2002/21/EC of the European Parliament and of the Council of 7 March 2002 on a common regulatory framework for electronic communications networks and services (Framework Directive), OJ L 108, 24.04.2002, pp. 33 - 50.

10 Directive (EU) 2018/1972 of the European Parliament and of the Council of 11 December 2018 establishing the European Electronic Communications Code, OJ L 321, 17.12.2018, pp. 36-214.

11 Dąbrowski, Ł.D., Wplyw decyzji Prezesa Urzędu Komunikacji Elektronicznej na handel między państwami członkowskimi Unii Europejskiej, in: Cała-Wacinkiewicz, E. (ed.), W jakiej Unii Europejskiej Polska - jaka Polska w Unii Europejskiej, Warszawa 2019, pp. 333 - 347.

12 Act of 17 November 1964 - the Code of Civil Procedure, Dz.U. (Journal of Laws) of 1964, no. 43 item 296, as amended.

13 Płoski, J. and Pacler, W., Administracja łączności i postępowanie kontrolne, in: Rogalski, M. (ed.), Prawo telekomunikacyjne, Warszawa 2011, p. 803.

14 Dąbrowski, Ł.D., Budowa wspólnego rynku ustug telekomunikacyjnych w Unii Europejskiej wybrane zagadnienia prawne, in: Barcik, J. and Półtorak, M. (eds.), Unia Europejska w przededniu Brexitu, Warszawa 2018, p. 247.

15 Dąbrowski, Ł.D., Obowiązki przedsiębiorców telekomunikacyjnych na rzecz obronności i bezpieczeństwa państwa, in: Gruszczak, A. (ed.), Meandry współczesnego bezpieczeństwa. Między regionalizacja a globalizacją, Kraków 2019, pp. $259-269$.

16 See: Dąbrowski, Ł.D., Postępowanie rezerwacyjne a postępowanie przetargowe - specyfika gospodarowania częstotliwościami w prawie telekomunikacyjnym, in: Wójcicka, E. (ed.), Gwarancje 
numeration (these decisions can be appealed in the judicial-administrative mode); they may also replace an agreement between parties. ${ }^{17}$ Decisions verified by the CCCP, in principle, impose on entrepreneurs only obligations. In the case of decisions: regarding access, specifying rates for ending connections in the network of a given operator or issued in litigations, imposing obligations on one operator is related to granting rights to the other. ${ }^{18}$ Judicial trials regarding appeals against decisions issued by the President of the OEC are usually long-lasting and the nature of cases is complex. Often many years pass between appealing the decision of the President of the OEC and the judicial decision issued by the CCCP or a legally binding conclusion of the appeal procedure. A change can be introduced both in factual and legal status of the heard (administrative) case in the course of the judicial procedure. It means the necessity to specify a moment proper for assessment of a given act issued by the President of the OEC for the purposes of resolving a legal case ultimately. The subject matter discussed herein concerns application of Article 316 of the CCP in a special procedure in telecommunications and mail regulation cases initiated as a result of the appeal against a decision issued by the President of the OEC. The problem of applying Article 316 of the CCP in telecommunications cases is not only an academic problem and continues to raise doubts in practice (the number of cases in which it is claimed that Article 316 of the CCP is infringed, is very high), ${ }^{19}$ and it concerns the fundamental issue of the civil procedure being the basis for judgement. The aim of the paper is to indicate that Article 316 of the CCP applies in telecommunications cases only in the scope in which without consideration thereof it would not be possible to issue a relevant judgement. ${ }^{20}$ However, in certain specific cases direct application thereof will not be appropriate. The source materials for the paper includes judicial decisions issued by the CCCP, appellate courts and the Supreme Court regarding telecommunications cases, as well as social security and energy regulation cases. Judicial decisions in social security and energy regulation cases, due to the major similarities of appeals against decisions issued by the Social Insurance Institution (ZUS) and the President of

praw jednostek $w$ postępowaniu administracyjnym i sądowoadministracyjnym, Częstochowa 2020, pp. $25-38$.

17 Dąbrowski, Ł.D., Wygaśnięcie decyzji Prezesa UKE zastępującej umowę stron w postępowaniu odwoławczym przed sqdem cywilnym, "Palestra" 2018, No. 3, pp. 81-85.

Dąbrowski Ł.D., Zastosowanie...., p. 158.

19 From 2013 to 2019 the allegation of infringing Article 316 of the Code of Civil Procedure in telecommunications cases constituted the grounds of appeals brought both by the President of the Office of Electronic Communications and telecommunications operators in hundreds of cases, and in the same number, constituted the grounds of cassations brought in.

See: Dąbrowski, Ł.D., Zastosowanie...., pp. 157-158. 
the Energy Regulatory Office (hereinafter: the President of the ERO), and appeals against decisions issued by the President of the OEC, may be per analogiam applied to telecommunication cases.

\section{Characteristics of a special procedure}

Due to its specific nature, a judicial procedure in telecommunications cases required detailed regulation in a form of a special procedure. ${ }^{21}$ Telecommunications cases, the hearing of which was attributed to ordinary courts, due to their essence are of public-legal character. Nevertheless, pursuant to legal regulations (Article $479^{57}$ of the CCP in conjunction with Article 206 of the TL), they have been included in the category of civil cases in the formal sense. ${ }^{22}$ In these cases, as civil cases, all procedural provisions apply, including Article 316 of the CCP while also considering regulations resulting from special procedures. ${ }^{23}$ In compliance with Article 316 par. 1 of the CCP in principio after closing the hearing, a court issues a judgement on the grounds of the facts existing at the moment of closing the hearing. The rule of adjudicating pursuant to Article 316 of the CCP is sometimes described as the rule of validity of a judicial decision. ${ }^{24}$ The facts taken into account by the court in issuing a judgement includes the factual and legal grounds of the judgement. ${ }^{25}$ Thus, the moment of adjudication is significant in and determines both scopes. ${ }^{26}$ On the grounds of telecommunications cases, due to their special character, it is, however, a theoretical possibility. ${ }^{27}$

While analysing the issue of applying Article 316 of the CCP in telecommunications cases, judicial decisions issued on the grounds of social security cases should be referred to in an auxiliary role. Such possibility is noticed by the Supreme

21 Ibidem, p. 160.

22 See more: Jakubecki, A. (ed.), Komentarz aktualizowany do ustawy z dnia 17 listopada $1964 r$. Kodeks postępowania cywilnego, LEX 2014.

23 See: Dąbrowski, Ł.D., Zastosowanie..., pp. 157-170.

24 Judgement of the Appellate Court in Łódź of 14 November 2013, I ACa 629/13, LEX No. 1396870; Judgment of the Supreme Court of 8 February 2006, II CSK 153/05, LEX No. 192012; Uliasz, M., Kodeks postępowania cywilnego. Komentarz, Warszawa 2008, p. 417.

25 Judgment of the Supreme Court of 8 February 2006, II CSK 153/05, LEX No. 192012.

26 Jakubecki, A., Komentarz do art. 316 Kodeksu postępowania cywilnego, in: Dolecki, H. and Wiśniewski, T. (eds.), Kodeks postępowania cywilnego. Komentarz. Tom I. Artykuły 1-366, LEX 2013.

27 Dolecki, H. and Wiśniewski, T. (eds.), Kodeks postępowania cywilnego. Komentarz. Tom II. Artykuły 367-505(37), LEX 2013. 
Court in judicial decisions issued in telecommunications cases. ${ }^{28}$ These are cases in which ordinary courts hear appeals against decisions issued by social security pension authorities; therefore, the characteristics of these cases are similar to appeals against decisions issued by regulatory authorities. A judicial procedure in social security cases is of an appeal character, since it is initiated as a result of an appeal brought by the insured against the decision issued by the Social Insurance Institution. The object of the procedure comprises assessment of compliance with the law of the decision issued by the social security pension authority. Verification of legality of the decision and issuance of a judicial decision thereof is possible only when considering the factual and legal status existing at the moment of issuance thereof, whereas the hearing of evidence before a court is a procedure verifying findings made by the social security pension authority. ${ }^{29}$

Furthermore, the specific character of a procedure before the CCCP initiated due to the appeal against a decision issued by the President of the OEC or the ERO, is undisputed. It is also initiated as a result of an appeal against an administrative decision, which replaces a suit; thus, it is also of an appellate character. The object thereof comprises assessment of compliance with the law, in both formal and substantive aspect, of a decision issued by a regulatory authority upon a motion of an entrepreneur or ex officio. Therefore, it is a procedure in the course of which the court is to strive for, if possible (if there are no special circumstances, e.g. impossible to be validated procedural irregularities of the authority), not only verifying findings made by the President of the OEC or the ERO, but also of the subjective hearing of the case as the first instance court in a contradictory procedure.

Two phases occur in such procedures: the first one being the special administrative procedure ending with issuance of a decision, whereas the second one, pending before an ordinary court according to the provisions of the CCP, ends with an issuance of a judgement. It is commonly believed in the judicial decisions and literature that these procedures are of a hybrid character. It means that these procedures combine elements of judicial first instance procedure with certain elements of second instance control of an administrative decision. This, in turn, means certain restrictions in invoking evidence other than evidence collected in the administrative procedure. These restrictions stem from, first of all, the scope of the decision and, second of all, the scope of the submitted appeal. ${ }^{30}$

28 Ruling of the Supreme Court of 4 March 2014, III SK 35/13, LEX No. 1463898; Decision of the Supreme Court of 20 February 2014, III SK 60/13, LEX No.1455740.

29 Judgement of the Supreme Court of 25 January 2005, I UK 152/04, LEX No. 154236.

30 Judgement of the Appellate Court in Warszawa of 8 March 2012, VI ACa 1150/11, LEX No. 1131091. 


\section{Verification of legality of decisions}

Specification of the role of an ordinary court in appeals against decisions issued by regulatory authorities constitutes a necessary condition preceding specification of a relevant scope of application of Article 316 of the CCP in telecommunications cases. ${ }^{31}$ The court 'reviews legality, as well as validity and advisability of the decision. ${ }^{32}$ Furthermore, it strives to determine factual circumstances of the case and then conducts legal assessment thereof in the scope of the validity of the appeal. ${ }^{33}$ The court adjudicates in the first instance, however, due to the validity of undertaking further measures by the court, it cannot omit verification of legality of an administrative act. Nevertheless, the court verifies legality of the decision in a limited scope, since the control of the public administration authority's activities in the view of the regulations of the CAP is restricted to the administrative court (Article 184 of the Constitution).

The judicial procedure is of an appellate character and the object thereof comprises assessment of compliance with the law of the issued decision. Therefore, in principle, the control role of the judicial procedure before a court concerns the facts on the day of issuing a decision by a regulatory authority. ${ }^{34}$ Since the court reviews legality of administrative acts, it applies the law binding on the day of issuance thereof and a divergence from a principle of verifying legality of decisions on the day of issuance thereof should be especially justified with circumstances of a given case. ${ }^{35}$ Judicial decisions of the Supreme Court of 15 January $2019^{36}$ or of 9 May $2019^{37}$, in social security cases, confirm the possibility of departing from application of Article 316 par. 1 of the CCP, however, only in an exceptional case. It concerns

31 Dąbrowski, Ł.D, Zastosowanie..., p. 165.

32 Judgment of the Supreme Court of 29 May 1991, III CRN 120/91, LEX No. 3724.

33 See: Judgment of the Supreme Court of 20 September 2005, III SZP 2/05, LEX No. 195802.

34 Dąbrowski, Ł.D., Ciężar dowodu w postępowaniu cywilnym i sądowoadministracyjnym w sprawach $z$ odwołań i skarg od decyzji Prezesa Urzędu Komunikacji Elektronicznej, in: Gil, D. (ed.), Dowodzenie $w$ postępowaniach sądowych w perspektywie porównawczej, Lublin 2016, p. 65.

35 See: Judgment of the Appellate Court in Poznań of 5 September 2013, III AUa 310/13, LEX No. 1363318; Judgment of the Appellate Court in Katowice of 9 July 2013, III AUa 1188/13, LEX No. 1349891; Judgment of the Appellate Court in Łodź of 11 September 2013, III AUa 1884/12, LEX No. 1372304; Judgment of the Appellate Court in Szczecin of 27 June 2013, III AUa 134/13, LEX No. 1369375; Judgment of the Appellate Court in Szczecin of 16 May 2013, III AUa 10/13, LEX No. 1369371; Judgment of the Appellate Court in Lublin of 17 April 2013, III AUa 215/13, LEX No. 1312060; Judgment of the Appellate Court in Kraków of 6 March 2013, III AUa 1249/12, LEX No. 1294803; Judgment of the Appellate Court in Kraków of 7 February 2013, III AUa 1079/12, LEX No. 1282647.

36 Decision of the Supreme Court of 15 January 2019, II UK 570/17, LEX No. 2605575.

37 Judgement of the Supreme Court of 9 May 2019, I UK 60/18, LEX No. 2692710. 
a situation when application of this provision would lead to a complete deprivation of significance of the administrative procedure. Despite the fact that a court hears a case in subjective terms as the first instance court, it reviews the administrative decision issued in an administrative procedure that preceded the judicial procedure. Thus, the ordinary court is obliged to refer to the facts existing on the day of issuing the decision. Therefore, the rule binding in the 'classic' civil procedure expressed in Article 316 par. 1 of the CCP, in compliance with which the court takes into consideration the facts as on closing the hearing, experiences an exception in a special procedure due to its specific appeal character. It concerns circumstances when the change to the factual and legal status after issuance of the decision is so significant that without consideration thereof it would not be possible to issue a relevant judgement, whereas in the CCCP judgement of 9 November $2017^{38}$ it was stated that premises that can be taken into consideration are not numerous and are treated exceptionally. These circumstances include e.g. the judgement of the Constitutional Tribunal stating that the provision constituting grounds for issuing a decision or amendment to the act constituting substantive-legal grounds in administrative procedure are not compliant with the Constitution. However, these are only exemplary circumstances. While taking into consideration the indicated arguments, circumstances of a specific case should be verified and there will only exceptionally be grounds for departing from the rule that the CCCP should focus on the date of issuing the decision while assessing how the premises that condition legality of the decision are met.

Substantive law provisions regulating a given legal relationship stipulate which provisions, hitherto binding or new, should be applied by the court to decide on the facts of the case pending before it. In principle, new or amended statutory regulations apply only to the future and are not binding with regard to the events occurring before the day of entering into force thereof. A departure from this rule must be explicitly provided for in the act itself. Therefore, the retroactive force of the provision cannot solely result from the purposes of the act, but primarily from its wording. ${ }^{39}$ In the judicial decisions issued by administrative courts it is also underlined that, in principle, the binding force of the administrative decision is not affected by an amendment or a revocation of a provision constituting legal grounds for issuance thereof. Nonetheless, slightly differently to the above judicial decision of the Supreme Court, it was decided that a departure from this rule is possible not only when new regulations influencing the hitherto contents of the legal grounds

38 Judgement of the Court of Competition and Consumer Protection of 9 November 2017, XVII AmE 77/14, LEX No. 2433392.

39 Ruling of the Supreme Court of 2 July 2004, II CK 421/03, LEX No. 174137. 
stipulate so, but also when it results from the entirety of regulations of a given subject matter. ${ }^{40}$ In case of changing legal provisions in the course of the judicial procedure, it should be considered whether amended substantive-legal provisions have retroactive force, since only then can this amendment have impact on the contents of the administrative decision. ${ }^{41}$

\section{Duration of procedure}

Due to the autonomy of the administrative procedure, a benchmark for the court should consist in the time when the decision establishing the rights and obligations of a telecommunications entrepreneur was issued. Judicial decisions of the Supreme Court taking into consideration this correlation adopted, that 'Article 316 par. 1 of the CCP should be applied with a consideration of characteristics of these cases determined by proper specification of the object of dispute between an entrepreneur and a regulator. ${ }^{2} 2$ The dispute between an entrepreneur and a regulator initiated with an appeal concerns legality and advisability (validity) of a decision issued by the President of the OEC. The court assesses the correctness of obligations imposed on telecommunications entrepreneurs in formal and substantive terms, ${ }^{43}$ in the scope indicated in the appea ${ }^{44}$ whereas the grounds for the decision are provided for by specific factual findings and legal status. The characteristic feature of civil law procedures in cases concerning appeals against administrative decisions is the possibility to supplement factual findings made in the administrative procedure. On the one hand, these activities depend on the evidence initiative of the parties, ${ }^{45}$ and on the other hand are limited with the scope of the decision itself and appeal against it. ${ }^{46}$ In compliance with the judicial decisions of the Supreme Court, the date of issuing the decision constitutes a caesura for determining facts of the case. However, the matter in question constitutes the situation in the market

40 Judgement of the Supreme Administrative Court of 19 December 2008, II OSK 1691/07, LEX No. 516054.

41 Siedlecko, W., Postępowanie cywilne, Warszawa 1972, p. 371.

42 Judgement of the Supreme Court of 12 April 2013, III SK 47/12, LEX No. 1375434.

43 Judgement of the Supreme Court of 13 August 2013, III SK 64/12, LEX No. 1380978.

44 Judgement of the Supreme Court of 3 October 2013, III SK 9/13, LEX No. 1391296; Judgement of the Supreme Court of 21 June 2013, III SK 36/12, LEX No. 1353231 and of 18 May 2012, III SK 37/11, LEX No. 1211167.

45 Judgement of the Supreme Court of 7 July 2011, III SK 52/10, LEX No. 1001322; Judgement of the Supreme Court of 13 August 2013, III SK 64/12, LEX No. 1380978.

46 Judgement of the Appellate Court in Warszawa of 8 March 2012, VI ACa 1150/11, LEX No. 1131091. 
covered with regulation and issues in operation thereof that require intervention that were identified by the President of the OEC. In the judicial decisions of the Supreme Court, ${ }^{47}$ the necessity of cautious application of Article 316 of the CCP was underlined in a situation when a dispute between telecommunications entrepreneurs and the President of the OEC, initiated with an appeal, concerns obligations shaped by the decision issued by the President of the OEC, which are imposed in a specific market situation and legal status. In fact, contrary to regular civil cases in which only a judgement issued by the court resolves rights and obligations of the parties to the procedure, in cases concerning appeals against decisions issued by the President of the OEC legal relationships between telecommunications entrepreneurs have already been established in a regulatory decision. ${ }^{48}$ In its judgement, the CCCP adjudicates on the legal personality of the appealed decision by dismissing the appeal or allowing the appeal in full or in part. In the first case, the court upholds the decision in the legal transactions and in the second case, the court eliminates the appealed decision from the legal transactions or upholds it in the legal transactions in an amended form. Therefore, the previous administrative procedure constitutes a necessary condition to initiate a contradictory judicial procedure. Therefore, the judicial possibilities of the CCCP are limited to the object of the appealed decision. This, in turn, means that the judicial procedure does not cover events that occurred after the decision had been issued and which were not covered with the administrative procedure. ${ }^{49}$

\section{Administrative penalties}

The confirmation of the thesis that each telecommunications regulation case should be heard considering special circumstances of each case can be found in judicial decisions on cases concerning appeals against administrative decisions under which penalties were imposed on telecommunications entrepreneurs. In compliance with the judicial decisions of the Supreme Court in judicial cases examining appeals against decisions of the President of OEC imposing monetary penalties, Article 316 of the CCP should be applied with special caution; any amendment to the legal status cannot, in fact, lead to deterioration of the legal situation of

\footnotetext{
47 Ibidem.

48 See: Dąbrowski, Ł.D., Regulowanie rynku telekomunikacyjnego przez Prezesa UKE - wybrane zagadnienia prawne, in: Bielecki, L. et al. (eds.), Szanse i bariery rozwoju przedsiębiorczości $w$ Polsce w ujęciu prawa publicznego oraz prawa prywatnego, Lublin 2017, pp. 169-181.

49 Judgement of the Appellate Court in Warszawa of 8 March 2012, VI ACa 1150/11, LEX No. 1131091.
} 
the appealing entrepreneur. ${ }^{50}$ In the light of the hitherto judicial decisions of the European Court of Human Rights, ${ }^{51}$ severe monetary penalties imposed on entrepreneurs by administrative authorities have a character of penal sanctions pursuant to the provisions of the European Convention on Human Rights. ${ }^{52}$ Considering that the procedure regarding administrative penalties imposed on the entrepreneur concerns penal sanctions, which is related to specific procedural guarantees for the punished entity, it is obvious that it is impossible to worsen the situation of such an entity on the grounds of regulations that entered into force after the event which the penalty concerns took place. It is an obvious conclusion also on the grounds of the Act of 6 June 1997 -Penal Code ${ }^{53}$ (Article 4 of the PC). Therefore, while considering the specific character of penal sanctions, the Supreme Court took a position against the possibility of applying subsequent wordings of provisions with regard to enterprises which committed an administrative offence before the provisions entered into force. However, it applies to amendments to the detriment of the entrepreneur. This thesis is confirmed with the judgement of the CCCP of 23 September 2019, ${ }^{54}$ in which it was stated that due to the amendment of provisions lowering the financial penalty for infringing the rules included in the Act of 20 February 2015 on renewable energy sources, ${ }^{55}$ pursuant to Article 316 of the CCP, the facts binding on the date of the CСCP adjudication, which was changed with regard to the facts binding on the date of examining the case by the President of the ERO, should have been taken into account in the scope of specifying the amount of the imposed monetary penalty. Therefore, the court in the said case applied milder conditions and applied more lenient provisions related to the monetary penalty with regard to the entrepreneur.

50 See also: Judgement of the Supreme Court of 21 September 2010, III SK 8/10, LEX No. 1113035; Judgement of the Supreme Court of 7 July 2011, III SK 52/10, LEX No. 1001322; Judgement of the Supreme Court of 9 March 2011, III SK 38/10, LEX No. 818606; Judgment of the Appellate Court in Warszawa of 4 June 2013, VI ACa 1493/12, LEX No. 1345576.

51 ECtHR, Garyfallou AEBE v Greece, Application no. 18996/91, 24.09.1997; ECtHR, Ioannis Haralambidis, Y. Haralambidis-Liberpa Ltd. v Greece, Application no. 36706/97, Second Section, 23.03.2000.

52 Dąbrowski, Ł.D., Cywilnoprawna kontrola decyzji administracyjnych Prezesa UKE nakładających kary finansowe na przedsiębiorców telekomunikacyjnych, in: Bieś-Srokosz, P. et al. (eds.), Wzajemne oddziaływanie gałęzi prawa publicznego i prywatnego, Częstochowa 2017, pp. 143 - 156.

53 Act of 6 June 1997 - Penal Code, Dz.U. (Journal of Laws) of 2014, item 538, as amended.

54 Judgement of the Court of Competition and Consumer Protection of 23 September 2019, XVII AmE 186/17, LEX No. 2747781.

55 Act of 20 February 2015 on renewable energy sources, Dz.U. (Journal of Laws) of 2015, item 478, as amended. 


\section{Relative decisions}

The general administrative decision (prior decision) constitutes the basis for an administrative decision subsequently issued in a special procedure (a derivative, relative, subsequent decision). This type of decisions usually issued in the case of specifying the rate for ending connections in mobile or landline networks. Under a general decision, the rate for a given operator is determined, whereas under consecutive bilateral (implementing) decisions it is implemented in relations between two entrepreneurs in their mutual settlements. ${ }^{56}$ The general decision 'constitutes a significant legislative fact in another, different administrative case in a situation, in which an administrative decision could not have been issued at all or an administrative decision of a specific wording without a legal or factual status established or stated under a previous administrative settlement of a different/separate case, could not have been issued. ${ }^{\prime 7}$ In other words, the general decision constitutes the basis of the bilateral decision. In the course of lawsuits concerning appeals against bilateral decisions, a general decision can be revoked due to the reasons affecting admissibility and correctness of establishing regulatory obligations. Thus, consecutive decisions based on the primary decision cannot remain in force. Since with regard to the effects of stating invalidity of the decision on which another relative decision is based, the Supreme Administrative Courts assumes that stating invalidity of the basic decision can constitute grounds for stating invalidity of the relative decision as issued with gross infringement of the law, ${ }^{58}$ it is admissible to adopt the interpretation in compliance with which revocation of the basic decision in telecommunications cases can justify revocation of the relative decision issued on the grounds of the basic decision..$^{59}$

It does not in any manner prevent from taking into consideration in the judicial procedure revocation of the decision of the President of OEC on the grounds of which telecommunications entrepreneur's obligations are established in consecutive decisions, when the decision was revoked due to reasons affecting admissibility or validity of establishing regulatory obligations in the primary decision on which consecutive decisions are based. ${ }^{60}$ From the point of view of the judicial proce-

56 It happens in the case of a dispute among operators and a lack of agreement regarding the implementation of a given rate under an annex to the interconnection agreement.

57 Resolution adopted by a panel of 5 Supreme Administrative Court judges of 9 November 1998, OPK 4/98, "Orzecznictwo Naczelnego Sądu Administracyjnego" 1999, No. 1, item 13.

58 Resolution of the Supreme Administrative Court of 13 November 2012, I OPS 2/12, LEX No. 1225395.

59 See e.g. Ruling of the Supreme Court of 8 May 2014, III SK 72/13, LEX No. 1482420.

60 Judgement of the Supreme Court of 3 October 2013, III SK 9/13, LEX No. 1391296. 
dure initiated by the appeal against the decision of the President of OEC, revoking the previous (prior) decision in the course of a special appeal procedure, on the grounds of which the consecutive decision has been issued, which is the subject of a different appeal procedure, is of great importance. It concerns the case when the previous (prior) decision had been revoked due to fundamental structural defects and it simultaneously constituted the primary source of obligations which were specified in the consecutive decision implementing obligations established in the previous decision to the bilateral interconnection cooperation. The basic premise for issuing the subsequent (consecutive) decision constituting (legal) grounds for issuance thereof did, in fact, disappear. Consecutive decisions implementing obligations specified in the revoked (prior) decision cannot be based on the decision which is affected by serious procedural defects. ${ }^{61}$

Additionally, revocation of a general decision leads to the disappearance not only of the legal grounds for issuing the relative decision, but also the disappearance of the factual grounds of issuing this decision and the possibility to verify the level of rates introduced by the President of the OEC on the grounds of the revoked decision. While issuing the consecutive decision, in principle, the President of the OEC bases on the findings made in the issuance of the general decision, and in case this decision has been validly revoked, related findings also cease to be binding. The relative decision does not, in principle, include calculations or analyses which would justify the amount of financial obligations specified therein, whereas both decisions are closely correlated.

Therefore, it is admissible to apply Article 316 par. 1 of the CCP when in the course of the judicial procedure initiated by the appeal against the subsequent (consecutive) decision, the previous (prior) decision was revoked on the grounds of which the telecommunications entrepreneur's obligations had been established in the subsequent (consecutive) decision. It concerns a situation when the previous (prior) decision was revoked due to structural defects resulting from not following legal procedures preceding issuance thereof, challenging its admissibility or validity of regulatory obligations provided for in the decision. ${ }^{62}$ This position was confirmed in numerous judicial decisions issued by district courts, appellate courts ${ }^{63}$

61 Judgement of the Supreme Court of 13 August 2013, III SK 64/12, LEX No. 1380978; Judgement of the Supreme Court of 24 September 2013, III SK 8/13, LEX No. 1380981.

62 Rulings of the Supreme Court of 20 February 2014, III SK 60/13, LEX No. 1455740; of 13 August 2013, III SK 64/12, LEX No. 1380978.

63 Decisions of the Appellate Court in Warszawa: of 11 January 2011, VI ACa 784/10, LEX No. 1369431; of 29 November 2011, VI ACa 553/11, LEX No. 1369428; of 14 December 2011, VI ACa 639/11, LEX No. 1238451; of 16 December 2011, VI ACa 916/11, LEX No. 1369434; of 14 February 2012, VI ACa 911/11, LEX No. 1369433; of 13 March 2012, VI ACa 1213/11, LEX 
and the Supreme Court ${ }^{64}$ on the grounds of cases concerning specification of rates for terminating connections in mobile networks.

\section{Conclusion}

The analysis of the Code of Civil Procedure's provisions does not give an unequivocal answer with regard to the date on which the meeting of the premises that condition legality of the administrative decision should be examined. As results from the hitherto judicial decisions of the Supreme Court, none of the CCP's provisions excludes application of Article 316 par. 1 of the CCP in these types of cases. ${ }^{65}$ However, it does not mean applying this provision without consideration of the characteristics thereof. ${ }^{66}$ While examining the case regarding an appeal against an administrative decision, the ordinary court reviews the legality, validity and advisability of the decision. Furthermore, it strives to determine the facts of the case and then conducts legal assessment thereof in the scope of the validity of the appeal. Thus, the court verifies correctness of the decision in substantive and formal terms. Therefore, it has the possibility to remedy certain defaults of the President of the OEC made before issuing the administrative decision. Nevertheless, this possibility is limited. The court should especially control, if on the date of issuance of the appealed decision the President of the OEC had the capacity to issue it, whether he or she properly specified the addressee (addressees) and met legal procedural requirements (in particular, consultation and consolidation procedures). In the case of stating defaults in this scope, it is necessary to revoke the appealed decision. These are defects of such gravity which cannot be corrected by the court in the civil procedure. Simultaneously, they prevent issuance of a relevant judicial decision. ${ }^{67}$

No. 1369404; of 27 March 2012, VI ACa 1219/11, LEX No. 1369406; of 22 February 2013, VI ACa 929/12, LEX No. 1369436; of 21 March 2013, VI ACa 1229/12, LEX No. 1314926; of 10 April 2013, VI ACa 1318/12, LEX No. 1369409; of 19 April 2013, VI ACa 379/12, LEX No. 1362977; of 23 April 2013, VI ACa 1499/12, LEX No. 1331151; of 25 April 2013, VI ACa 1317/12, LEX No. 1369442; of 18 July 2013, VI ACa 1590/12, LEX No. 1400503.

64 Rulings of the Supreme Court: of 20 March 2013, III SK 35/12, LEX No. 1318420; of 6 March 2013, III SK 32/12, LEX No. 1331341; of 13 December 2012, III SK 24/12, LEX No. 1238117; of 11 April 2012, III SK 41/11, LEX No. 1238126; of 12 April 2013, III SK 47/12, LEX No. 1375434; of 5 June 2013, III SK 54/12, LEX No. 1391292; of 27 March 2014, III SK 68/13, LEX No. 1463903; of 27 March 2014, III SK 69/13, LEX No. 1463904; of 27 March 2014, III SK 67/13, LEX No. 1463902; of 8 May 2014, III SK 72/13, LEX No. 1482420.

65 See, among others: Judgement of the Supreme Court of 17 March 2010, III SK 40/09, LEX No. 987815.

66 Ruling of the Supreme Court of 20 February 2014, III SK 60/13, LEX No. 1455740.

67 Among others, Judgement of the Supreme Court of 5 January 2011, III SK 34/10, LEX No. 1130869. 
However, contrary to the administrative court, the civil court does not examine the administrative decision as the act of application of the law. Therefore, it does not control the activity of the President of the OEC as the public administration authority in the light of the CAP's provisions. It is aimed at substantive verification of the decision issued by the President of the OEC in the scope of the dispute arising as a result of issuing the decision questioned by the telecommunications entrepreneur.

In telecommunications cases, on the one hand, the principle specified in Article 316 par. 1 of the CCP regarding adjudicating according to the state of affairs as on the closing of the hearing, is binding; however, on the other hand, the correctness and legality of the decision is assessed according to the state of affairs as on the moment of issuance thereof. Application of Article 316 of the CCP should be considered ad casum so that its application does not lead to distortion of the nature of proceedings in telecommunications cases. There cannot be a situation when the administrative procedure preceding the judicial procedure is rid of significance. ${ }^{68}$ Therefore, Article 316 par. 1 of the CCP is infringed only when the change in the factual and legal status after issuance of the decision of the President of the OEC is so significant that without consideration thereof it would not be possible to issue a proper judgement. In other cases, the principle of assessing the correctness of decision according to the status existing on the day of issuance thereof, is binding. Despite the fact that the CCCP examines the case substantively as the first instance court and thus, re-examines the case, as a control authority towards the regulatory authority, it is obliged to refer to the legal and factual status existing on the day of issuance of the decision. Thus, the rule binding in the lawsuit stipulated in Article 316 par. 1 of the CCP is an exception in the special procedure in telecommunications regulation cases due to its special appeal nature.

\section{References}

Dąbrowski, Ł.D., Wplyw decyzji Prezesa Urzędu Komunikacji Elektronicznej na handel między państwami członkowskimi Unii Europejskiej, in: Cała-Wacinkiewicz, E. (ed.), W jakiej Unii Europejskiej Polska - jaka Polska w Unii Europejskiej, Warszawa 2019.

Dąbrowski, Ł.D., Budowa wspólnego rynku usług telekomunikacyjnych w Unii Europejskiej - wybrane zagadnienia prawne, in: Barcik, J. and Półtorak, M. (eds.), Unia Europejska w przededniu Brexitu, Warszawa 2018.

68 See: Judgement of the Appellate Court in Łódź of 14 September 2018, III AUa 1249/17, LEX No. 2578776. 
Dąbrowski, Ł.D., Obowiązki przedsiębiorców telekomunikacyjnych na rzecz obronności i bezpieczeństwa państwa, in: Gruszczak, A. (ed.), Meandry współczesnego bezpieczeństwa. Między regionalizacją a globalizacją, Kraków 2019.

Dąbrowski, Ł.D., Postępowanie rezerwacyjne a postępowanie przetargowe - specyfika gospodarowania częstotliwościami w prawie telekomunikacyjnym, in: Wójcicka, E. (ed.), Gwarancje praw jednostek w postępowaniu administracyjnym i sądowoadministracyjnym, Częstochowa 2020.

Dąbrowski, Ł.D., Wygaśnięcie decyzji Prezesa UKE zastępującej umowę stron w postępowaniu odwoławczym przed sądem cywilnym, "Palestra" 2018, No. 3.

Dąbrowski, Ł.D., Zastosowanie art. 321 k.p.c. w sprawach $z$ odwołań od decyzji Prezesa Urzędu Komunikacji Elektronicznej, "Ius Novum” 2016, No. 4.

Dąbrowski, Ł.D., Odmowa wydania decyzji przez Prezesa Urzędu Komunikacji Elektronicznej w świetle art. 28 ustawy prawo telekomunikacyjne, "Ius Novum” 2016, No. 3.

Dąbrowski, Ł.D., Ciężar dowodu w postępowaniu cywilnym i sądowoadministracyjnym w sprawach $z$ odwołań i skarg od decyzji Prezesa Urzędu Komunikacji Elektronicznej, in: Gil, D. (ed.), Dowodzenie w postępowaniach sądowych w perspektywie porównawczej, Lublin 2016.

Dąbrowski, Ł.D., Regulowanie rynku telekomunikacyjnego przez Prezesa UKE - wybrane zagadnienia prawne, in: Bielecki, L. et al. (eds.), Szanse i bariery rozwoju przedsiębiorczości w Polsce - w ujęciu prawa publicznego oraz prawa prywatnego, Lublin 2017.

Dąbrowski, Ł.D., Cywilnoprawna kontrola decyzji administracyjnych Prezesa UKE nakładajacych kary finansowe na przedsiębiorców telekomunikacyjnych, in: Bieś-Srokosz, P. et al. (eds.), Wzajemne oddziaływanie gałęzi prawa publicznego i prywatnego, Częstochowa 2017.

Jakubecki, A. (ed.), Komentarz aktualizowany do ustawy $z$ dnia 17 listopada 1964 r. Kodeks postępowania cywilnego, LEX 2014.

Jakubecki, A., Komentarz do art. 316 Kodeksu postępowania cywilnego, in: Dolecki, H. and Wiśniewski, T. (eds.), Kodeks postępowania cywilnego. Komentarz. Tom I. Artykuły 1-366, LEX 2013.

Kledzik, P., Postępowanie przed Prezesem Urzędu Komunikacji Elektronicznej, in: Babis, H. and Flaga-Gieruszyńska, K. (eds.), Rynek usług telekomunikacyjnych, Warszawa 2011.

Piątek, S., Prawo telekomunikacyjne. Komentarz, Warszawa 2013.

Płoski, J. and Pacler, W., Administracja łączności i postępowanie kontrolne, in: Rogalski, M. (ed.), Prawo telekomunikacyjne, Warszawa 2011.

Siedlecko, W., Postępowanie cywilne, Warszawa 1972.

Śladkowska, E., Wydanie decyzji administracyjnej bez podstawy prawnej lub z rażacym naruszeniem prawa w ogólnym postępowaniu administracyjnym, Warszawa 2013.

Uliasz, M., Kodeks postępowania cywilnego. Komentarz, Warszawa 2008. 


\section{CITATION}

Dąbrowski, Ł. D., Application of Article 316 of the Polish Code of Civil Procedure in the appeals against decisions of the President of the Office of Electronic Communications "Acta Iuris Stetinensis" 2020, No. 3 (Vol. 31), 5-21, DOI: 10.18276/ais.2020.31-01. 